\title{
Some Policies Can Not Wait
}

\section{Zoltan Lugosi}

The role of prisoner is not an easy one and there is no school that teaches people how to do time. Neither does the system of corrections provide adequate programs to help prisoners develop more positive attitudes and lifestyles in order for them to adapt to society. Therefore, it is left to prisoners to learn, and misconceptions and misinterpretations are maintained. These ill-informed beliefs include the widely misunderstood illness of HIV/AIDS. While there is a need to re-evaluate the concepts of rehabilitation, a more urgent need is the education of prisoners and prison staff regarding the facts, prevention and treatment of HIV/AIDS.

People fail to realize the scope of the crisis. AIDS kills, and it kills slowly and painfully. To date, there is no cure but there are means of prevention and there are treatments to improve and prolong life once a person has an HIV infection. Without education and the means of prevention, HIV infection will become an epidemic in prisons as it already is in some communities. Without education about treatment and access to proper medical care, AIDS will result in enormous suffering in prisons, much of it avoidable and unnecessary.

Although there are more ways to get this illusive virus, unprotected sexual intercourse and the sharing of unclean needles are the two most common. No matter what one's moral point of view, no matter what laws are proclaimed, people will continue to have sex and shoot up. And Canadian prisons are merely a statistical microcosm of society.

HIV/AIDS is not confined to the IV drug user or gay communities. A recent University of Toronto study of newborns "revealed that the rate of the virus is three times higher than expected" ("test finds three times more HIV babies than expected,"Oct. 26, 1990:A1). The study suggests that the HIV virus is "spreading dangerously among women of child bearing age" (ibid.). As of September, 1990 "fifty-six 
children in Canada" (ibid) have contracted HIV/AIDS. Furthermore, there are an estimated 4500 AIDS cases and 30,000 to 50,000 cases of HIV infection among Canadians. Without specific testing, the real figures will never be known.

Finally recognizing that HIV/AIDS will not simply go away and will remain a growing concern, Parliament commissioned the Parliamentary ad hoc Committee on AIDS in 1989 (PCA). In June of 1990 , PCA made fifty recommendations on HIV/AIDS treatment, prevention, and education, including five very specific recommendations that targeted the captive populations of prisons. These recommendations include "that the Solicitor General begin as soon as possible to implement the recommendations of NAC-AIDS [National Action Committee AIDS] ... for the prevention of HIV transmission in prisons" (PCA,1990:52), and, in particular, to make available bleach and condoms to prisoners, to make a pilot study to assess the level of infection in federal prisons, to provide funding for community groups to mount AIDS education and awareness programs in prisons, and to undertake a study of the advantages of prison health care services being provided by outside agencies (Ibid.:5254). The committee's report noted U.S. prison statistics which "show that 18 to $28 \%$ of populations engage in unprotected sexual activity and $50 \%$ of inmates may be involved in drug use and that sharing of needles is common (ibid:47)

Federal Health and Welfare Minister Perrin Beatty and his department quickly responded to the various Parliamentary committee recommendations with a national AIDS strategy presented as a two-part plan: HIV and AIDS: Canada's Blueprint and Building an Effective Partnership: The Federal Government's Commitment to Fighting AIDS. This plan calls for the development of policies, programs and activities for AIDS education, treatment and prevention. The strategy's "Guiding Principles" claim that "everyone must be involved [and] no substantial achievement can be realized unless full cooperation exists between Canadians, governments at all levels as well as AIDS service organizations, persons living with AIDS, non-governmental organizations, professional associations, community groups, researchers, healthcare and social service 
providers, the private sector and labour organizations" (Health and Welfare Canada, 1990:39). Nonetheless, the plan completely ignores the PCA recommendations concerning prisons, prisoners and prison staff. And this in spite of the fact that Mr. Beatty himself made a point of touring Canadian prisons in 1985 as Solicitor-General and is well aware of conditions.

Confronted by the Canadian AIDS Society about the omission of prisons as a special target area in his AIDS strategy, Beatty responded "that direct action to fight the spread of AIDS in prison requires the cooperation of the Solicitor-General, who apparently is not convinced there is a problem" (RLGL, 1990). Officials believe that because sex and drugs are proscribed in prison, the problems of HIV/AIDS do not exist.

Canadians are certainly not unfamiliar with Parliamentary Commissions. They are set up to address specific crises and normally seek the guidance and advice of the public and private sectors. As a result, many professional recommendations are made and, over the years, many reports containing worthwhile solutions and conclusions and results have been compiled. Several of these commissions addressed specific concerns within the Correctional System of Canada (CSC). For example, the recent Daubney Commission reported its findings and recommendations in an extensive paper, $\boldsymbol{T} \boldsymbol{a} \boldsymbol{k} \boldsymbol{i n} \boldsymbol{g}$ Responsibility, regarding parole and other aspects of the justice system, including the myths and realities of prisons. Millions of tax dollars pay for these reports, papers continue to pile up, but the reports made by experts from various fields fall on deaf ears. Having studied the Schwackhammer Inquiry, the report of the Daubney Commission and the Pepino Inquiry and having experienced the conditions of various Canadian penitentiaries, I can assure you that the recommendations made concerning very real crisis situations have not been put into effect.

The primary mandate of the CSC is to protect society. That does not necessarily mean that public safety is ensured simply because offenders are locked away in prisons. Whether or not people believe it, prisoners are eventually released and prisoners 
in institutions do have basic rights. To deny prisoners their rights, or to deny offenders the opportunity to lead positive and healthy lifestyles within prison or community settings, does nothing to protect society. The high rate of recidivism in Canada reflects this. And it is fact that, with the exception of the United States, Canada has the highest rate of incarceration in the western world. (Elvin, 1991). Because prisoners will be released at one time or another, they must be educated about HIV/AIDS and given the means to protect themselves from it or there is a very real threat of HIV/AIDS transmission into the community at large. To deny prisoners explicit education, the opportunity to protect themselves, and the specialized medical care they require are direct contradictions of the mandate of CSC, as defined in its "Mission Statement." Based upon CSC's response to HIV/AIDS, this federally released statement on the goals and objectives of prisons, is not worth the paper it is printed on.

However, governments are beginning to feel pressure from those who no longer want reports or "Mission Statements". They want to see the necessary action to enact and realize needed policies. And no matter how much people claim that policy and legislation are Cabinet matters, it is and always will be public pressure that initiates action. Nevertheless, it seems that every issue, whether social, economic or whatever, gets bogged down in political and bureaucratic processes and people continue to suffer because of rhetoric and inaction.

But some things can not just wait. HIV/AIDS can not/will not wait for the politicians to make up their minds. People must act now.

Some Canadians, besides the prisoners, have recognized the urgent need to deal with the HIV/AIDS epidemic in prisons. A coalition of AIDS activists, ACT UP MONTREAL recently formed a Prisoners Rights Committee. Recognizing that Canada's National AIDS Strategy included nothing for prisoners, they have unleashed their power through direct action. This has taken the form of a demonstration and an outreach program. On Prisons' Justice Day in 1990, they demonstrated outside the Federal Health and Welfare Department's offices in Montréal 
and were granted an audience with Health and Welfare Canada representatives who explained that prisons are the responsibility of the Solicitor-General, not Health and Welfare. ACT UP MONTREAL remains determined to bring attention to the AIDS crisis in prisons through government enactment of policies that will address HIV/AIDS - education, prevention, and treatment.

\section{PREVENTION}

After hearing volumes of expert testimony, PCA stated: "There is thus undoubtedly a high incidence of high risk behavior [in Canadian prisons]" (PCA, 1990: 47). It is obvious that the distribution of condoms and bleach (to disinfect needles) will only make what is already happening safer. Corrections officials are adamant that this practice will only encourage sex and drugs, but that is another myth and a simple denial of what goes on in their institutions. As punishment has never been a deterrent for crime, neither is the threat of contracting HIV/AIDS a deterrent for drugs and sexual activity. And prison policy, mostly based on security measures, includes nothing to address the wide-spread panic, cell-block disturbances and the erosion of correctional budgets that are or will be, a result of the lack of HIV/AIDS education. By denying that there is an HIV/AIDS problem in Canadian prisons, prison administrators are only frustrating the efforts of community groups who express their concern and desire to be involved in prison programs.

\section{TREATMENT}

Prisoners with HIV/AIDS need alternatives to segregation. We have learned that this deadly infection is not as readily communicable as once believed, so there is no need to isolate prisoners with HIV/AIDS or treat them substantially different from the general prison population. There is, however, an urgent need for sensitivity to these prisoners' feelings and health requirements - they are facing certain death and need help to cope with grief and other emotional problems. They know that, without the specialized medical attention which they will not receive in a Canadian prison, they are facing terrible physical suffering. Strangely enough, there is more fear among prison 
staff than prisoners. Dying of AIDS is painful enough. To have to endure death in isolation among people who are afraid of, and therefore hostile towards, persons with AIDS is a violation of basic human rights.

\section{EDUCATION}

While there is a need for films to educate prison workers, general populations of all prisons need explicit HIV/AIDS education presented by recognized community educators. Meanwhile, Narcotics Anonymous and substance abuse coordinators must be encouraged to include the facts on HIV/AIDS in their counseling. Because the real obstacle for prisoner involvement in HIV/AIDS programs is often homophobia, there is a need for proper presentation of these programs, if only to convince prisoners that the most exposed are those who use, or have used, needles. And because prisoners distrust prison authorities and are unlikely to discuss proscribed activities, peer groups and programs are the best approach. Prisoner ingenuity ought to spread knowledge, not AIDS.

American prison rights activist David Gilbert, with the help of community support groups and AIDS professionals, launched a prisoners' education project on HIV/AIDS at the Auburn Correctional Facility in New York. This eventually led to his involuntary transfer to the highest security institution in the state. But before Gilbert was shipped, he was able to draw some conclusions about his experiences with constant hassles and delays:

"thorough, consistent and ongoing peer education can make a big difference in the attitudes and practices of prisoners; there must be strong public pressure for such programs; there must be a powerful movement about AIDS to push the professionals to be true to their professed ideals and put the fight against AIDS above careerism. To be effective against AIDS, the movement must consciously oppose race, class, gender and sexual-orientation biases" (Gilbert, 1989:143-44).

There is enough known about HIV/AIDS to dispel the myths. We know how to prevent it and, if not yet how to cure it, to make it a manageable chronic illness. And there is no doubt that 
Journal of Prisoners on Prisons, Vol. 3, No. 1/2, Spring, 1991

we can teach others what we know. However, prison authorities and politicians refuse to recognize the crisis when confronted on their inaction. Their Commissions and recommendations and studies are only a continuation of their rhetoric. The studies have been done, the recommendations have been made, we need direct action now.

\section{REFERENCES}

Elvin, J. (Winter, 1991) "U.S. Now Leads World in Rate of Incarceration", The National Prison Project Journal, 6 (1):1-2.

Gilbert, D., (1989) "The Struggle for AIDS Education in Prison", New Studies on the Left, 14 (1/2):143-44.

Health and Welfare Canada (June, 1990) HIV and AIDS: Canada's Blueprint, Ottawa: Ministry of Supply and Services.

PCA, Report of The Parliamentary Ad Hoc Committee on AIDS (June, 1990) Confronting a Crisis, Ottawa: Ministry of Supply and Services.

RLGL, Rites for Lesbian and Gay Liberation (August, 1990) Canada's AIDS Strategy: Nothing for Prisoners, Not Much For Anyone, Toronto.

"Tests find three times more HIV babies than expected" (October 26, 1990) The Hamilton Spectator:A1. 
